\title{
An attempt to prepare Macrophyte Index for Rivers for assessment watercourses in Kazakhstan
}

\author{
Ruslan Muratov, Aizhan Zhamangara, Raikhan Beisenova, Lyailya Akbayeva \\ L.N. Gumilyov Eurasian National University, Faculty of Natural Sciences, Astana, Mirzoyana Street 2, Kazakhstan, \\ e-mail:muratov_rus@mail.ru
}

Krzysztof Szoszkiewicz, Szymon Jusik, Daniel Gebler

Poznań University of Life Sciences, Department of Ecology and Environmental Protection, 60-637 Poznań, Wojska

Polskiego Street 28, Poland,e-mail: kszoszk@up.poznan.pll

\begin{abstract}
Monitoring of water ecosystems in Kazakhstan is based generally on chemical indicators. Biological indicators, such as macroinvertebrates and a phytoplankton are rarely used. Sometimes some macrophyte species of are used for the assessment of water quality. The aim of the study was to analyse the possibilities of the introduction of the Polish monitoring system based on aquatic plants for rivers in Kazakhstan watercourses. The Polish method uses the Macrophyte Index for Rivers (MIR) and it has been prepared for the purposes of the EU Water Framework Directive. The systematic structure of Kazakhstan's water plants were analyzed and compared with the macrophyte list of Poland. Flora of Kazakhstan was used as the main source of information and some recent publications were analyzed as well. It was found that the aquatic flora of Kazakhstan is rich and a total of 240 taxa of emergent and submerged plants are identified in the country. We have confirmed that a large number of aquatic plants recorded in Kazakhstan are recognized as bioindicators. The ecological tolerance and sensitivity of the identified bioindicators was analysed. A preliminary nine taxa with the the highest indicator weight in the MIR system $(\mathrm{W}=3)$ were detected as the most sensitive indicators in Kazakhstan flora: Sciuro-hypnum plumosum, Scapania sp., Ceratphyllum demersum, C. submersum, Potamogeton lucens, P. praelongus, Lemna gibba, Menyanthes trifoliata and Acorus calamus. It was found that the MIR index can be applied in Kazakhstan, especially if we enrich the list of indicative species with the local macrophytes, which were not included in the original version. The list of potential indicator-species includes: Ranunculus altaicus, Ranunculus natans, Althenia filiformis, Nelumbo nucifera, Trapa incise which does not occur in Europe and Nuphar pumila, Nymphoides peltata, Ranunculus rionii, Rorippa palustris, Trapa natans, Utricularia intermedia, U. minor, Eleocharis acicularis and Vallisneria spiralis.
\end{abstract}

Keywords: biological monitoring, macrophytes, indicator species, bioindication, rivers, Kazakhstan

Submitted 3 March 2015, revised 15 May 2015, accepted 30 September 2015

\section{Introduction}

Water monitoring in Kazakhstan has a long tradition. It has been introduced in 1959 for lakes as well as for rivers. Currently water monitoring includes regular observation of the state of water bodies and is based on a range of physicochemical parameters (Republican State Enterprise 2013). It contains running and standing waters as well as groundwater. The monitoring system is relatively well organizes but the frequency of sampling is often insufficient and some seasons of the year are not covered by the comprehensive observations. Moreover, systematic observations of diffuse pollutants entering water bodies with surface runoff is completely absent and on large farm territories intensive use of mineral fertilizers and pesticides takes place (Water resources of Kazakhstan 2014).
Bioindicator characteristics of some aquatic and shore plants are sometimes used for general assessment of wetlands (Ospanov, Stamkulova 2012). However, the assessment of water ecosystems on the basis of biological elements not exists in Kazakhstan, whereas the response of aquatic organisms to environmental factors is widely utilised in other countries, especially in European Union.

In the year 2000, the Water Framework Directive (Directive 2000/60/EC) was established in the EU; this introduced biological methods as principal for the assessment of freshwater ecosystems. The physical and chemical approaches are only used in supporting the biological methods. Macrophytes, which are aquatic plants, belong to the group of organisms which have been included into the monitoring under WFD (Directive 2000/60/EC) and they are an obligatory element for the assessment of running and standing waters. For the purpose of river monitoring, 
several systems based on aquatic plants have been developed and some of them have been integrated into national monitoring programmes, e.g. in Denmark (Svendsen, Rebsdorf 1994), Germany (Schaumburg et al. 2004), France (Haury et al. 2006), UK (Holmes et al. 1999) and Poland (Szoszkiewicz 2010).

There are numerous advantages to utilising macrophytes in monitoring. Macrophytes are objects visible to the naked eye and therefore convenient for observation. They allow a first approximation to visually assess the ecological status of the water body, and make it possible to determine the trophic properties of water (Semin, Freyndling 1988; Haury et al. 1996; Holmes et al. 1999; Schneider et al. 2000; Haury et al. 2006) and acidification (Tremp, Kohler 1995).

The aim of the study was to analyse the possibilities of the introduction the Polish macrophyte-based monitoring system for rivers in Kazakhstan watercourses. The Polish method uses the Macrophyte Index for Rivers MIR (Szoszkiewicz 2010) which has been prepared and introduced into monitoring according to the EU Water Framework Directive.

\section{Methods}

In the first step of analysis, we completed the list of aquatic plants for Kazakhstan. The most extensive list of aquatic species in Kazakhstan comes from the books Flora of Kazakhstan by Pavlov (1956-1966) and Flora of Kazakhstan by Baitenov (1999). Moreover, numerous species were recorded in two other sources: Flora and vegetation waters of Northern Kazakhstan by Sviridenko (2000), Flora in the West Kazakhstan steppe province reservoirs (Shadrina 2007) and Biological Diversity by Krainyuk et al. (2005). Among the scientific articles, one of the most remarkable is Moss flora around the lake Dubygalinskoe East Kazakhstan region by Nesterova et al. (2013). Information about the aquatic flora of Kazakhstan can also be gathered from the following online resources: Federenko (2011), Protected natural territories of Central Asia and Kazakhstan (2007), The Global Biodiversity Information Facility (2013).

Analysing the accomplished pool of aquatic species, we selected the set of potential macrophyte indicators in Kazakhstan. We considered the list of indicative species which is utilized in Poland. The list of indicative aquatic plants for Poland is based on species used for the calculation of Polish macrophyte index MIR. The list of MIR species growing in Kazakhstan was analysed considering their species indicator value $(\mathrm{L})$ and species weighting factor $(\mathrm{W})$. The $\mathrm{L}$ value ranges from 1 (indicators of europhic conditions) to 10 (indicators of oligotrophic water). The $\mathrm{W}$ value ranges from 1 (plants with a large range tolerance to trophy - eurybionts) to 3 (organisms of a narrow tolerance scope - ecological specialists, stenobionts).Finally, the initial list of potential indicative macrophytes for the Kazakhstan was enlarged by selecting the pool of aquatic plants growing in Kazakhstan, which are not recorded in Poland.

\section{Study area}

Kazakhstan is a large country located in the center of the Eurasian continent with an area of 2,724.9 thousand $\mathrm{km}^{2}$, it occupies the middle and southern latitudes of the temperate zone. Major part of the area of Kazakhstan belongs to Asia $(80,4 \%)$ and the rest belongs to Europe.

The nature of the hydrographic network, and the river flow regime, is extremely variable in Kazakhstan due to large differences of latitude, altitude and also differences in climate and landscape zones. Large areas suffer a lack of moisture, which is especially pronounced in the desert areas, the small river network runoff is very sparse and the rivers are shallow. Nevertheless the country has more than 39,000 permanent and temporary streams, and within this number there are about 7,000 rivers longer than $10 \mathrm{~km}$. Some of these are: the Irtysh, Yesil, Tobol, Ural, Syr Darya, Ili, Chu, which are much longer than $1000 \mathrm{~km}$ (Vilesov et al. 2009).

\section{Results}

\subsection{Aquatic flora in Kazakhstan}

Conducted analysis of the state of the flora in Kazakhstan showed a large number of aquatic species (Pavlov 1956-1966; Baitenov 1999; Sviridenko 2000; Shadrina 2007; Federenko 2011, Protected natural territories... 2007, The Global Biodiversity Information Facility 2013). A total of 240 taxa of emergent and submerged plants were found. The dominant group, consisting of 143 species, is vascular plants ( $60 \%$ of all aquatic flora). This group consists of 88 monocotyledons, 51 dicotyledons and 4 ferns.

Another group of aquatic plants are bryophytes, of which 41 taxa have been recorded in Kazakhstan (16\% of all aquatic flora). This group of plants consists of 32 species of mosses and 8 liverworts. The last group is algae which is dominated by microscopic taxa but only large macroscopic and structural forms are included to macrophytes. In this group 57 taxa (24\% of all aquatic flora) are recorded in Kazakhstan, mostly Charophytes. 


\subsection{Comparision of aquatic flora between Poland and Kazakhstan}

Our analysis revealed that a large number of aquatic plants recorded in Kazakhstan are utilized as bioindicators in biological monitoring for the ecological status assessment in rivers in Europe. Taking into account the Polish MIR monitoring method we have confirmed the presence of 94 indicator species in the rivers of Kazakhstan. The full list of MIR indicator species growing in Kazakhstan is presented in table 1 .

The estimated number of 94 species in aquatic ecosystems of Kazakhstan is $62 \%$ of all indicator species used in the MIR system. Among these species vascular plants are particularly strongly represented - 70 of them were found. It is about $74 \%$ of the full set of MIR vascular plants. Macrophyte flora of other groups is still not well identified and only about $18 \%$ of bryophytes and $7 \%$ of algae from the MIR system are recorded in Kazakhstan, table 2.

Ecological properties of indicative macrophytes occurring in Kazakhstan are shown in fig. 1 and 2. Concerning the indicator value (fig. 1), the overrepresentation of species indicating medium trophy level was observed (L value ranging from 4 to 6 ). The very low number of species indicating oligotrophic water ( $\mathrm{L}$ value between 1 and 5) was revealed. There was only one taxa (Sphagnum $s p$.) with the $\mathrm{L}$ value equal to ten among the MIR indicators found in Kazakhstan.

Concerning the weighting factor (fig. 2), the very low number of ecological specialists as most sensitive indicators was observed in Kazakhstan flora - only nine taxa with the $\mathrm{W}=3$ were detected. These are two bryophytes (Sciuro-hypnum plumosum, Scapania sp.) and seven vascular plants - submerged (Ceratophyllum demersum, Cer-

Table 1. The list of aquatic taxa of Kazakhstan that are included in the method Macrophyte Index for Rivers. Abbreviations: MIR Macrophyte Index for Rivers, $\mathrm{L}$ - species indicator value, $\mathrm{W}$ - species weighting factor

\begin{tabular}{|c|c|c|c|c|c|c|c|c|}
\hline \multirow{2}{*}{ Species } & \multicolumn{2}{|c|}{ MIR } & \multirow{2}{*}{ Species } & \multicolumn{2}{|c|}{ MIR } & \multirow{2}{*}{ Species } & \multicolumn{2}{|c|}{ MIR } \\
\hline & $\mathrm{L}$ & $\mathrm{W}$ & & $\mathrm{L}$ & $\mathrm{W}$ & & $\mathrm{L}$ & $\mathrm{W}$ \\
\hline \multicolumn{3}{|l|}{ ALGAE } & Callitriche palustris & 6 & 1 & Catabrosa aquatica & 5 & 1 \\
\hline Chara sp. & 6 & 2 & Caltha palustris & 6 & 1 & Eleocharis palustris & 6 & 2 \\
\hline Cladophora sp. & 1 & 2 & Ceratophyllum demersum & 2 & 3 & Elodea canadensis & 5 & 2 \\
\hline Enteromorpha sp. & 1 & 2 & Ceratophyll. submersum & 2 & 3 & Glyceria fluitans & 5 & 2 \\
\hline Lyngbya sp. & 6 & 2 & Cicuta virosa & 6 & 2 & Glyceria maxima & 3 & 1 \\
\hline Mougeotia sp. & 3 & 1 & Hippuris vulgaris & 4 & 1 & Hydroch. morsus-ranae & 6 & 2 \\
\hline Oedogonium sp. & 2 & 1 & Lysimachia vulgaris & 4 & 1 & Iris pseudacorus & 6 & 2 \\
\hline Spirogyra sp. & 4 & 1 & Mentha aquatica & 5 & 1 & Lemna gibba & 1 & 3 \\
\hline \multicolumn{3}{|l|}{ LIVERWORTS } & Menyanthes trifoliata & 9 & 3 & Lemna minor & 2 & 2 \\
\hline Pellia sp. & 7 & 2 & Myosotis palustris & 4 & 1 & Lemna trisulca & 4 & 2 \\
\hline Porella cordeana & 6 & 1 & Myriophyllum spicatum & 3 & 2 & Phalaris arundinacea & 2 & 1 \\
\hline Riccia fluitans & 5 & 1 & Myriophyll. verticillatum & 5 & 2 & Potamogeton alpinus & 7 & 2 \\
\hline Scapania sp. & 9 & 3 & Nasturtium officinale & 5 & 2 & Potamoget. berchtoldii & 5 & 2 \\
\hline \multicolumn{3}{|l|}{ MOSSES } & Nuphar lutea & 4 & 2 & Potamoget. compressus & 4 & 2 \\
\hline Brachythecium mildeanum & 3 & 2 & Nymphaea alba & 6 & 2 & Potamogeton crispus & 4 & 2 \\
\hline Brachythecium rivulare & 8 & 2 & Oenanthe aquatica & 5 & 1 & Potamogeton friesii & 3 & 2 \\
\hline Bryum sp. & 6 & 1 & Polygonum amphibium & 4 & 1 & Potamogeton gramineus & 7 & 1 \\
\hline Cratoneuron sp. & 8 & 2 & Polygonum hydropiper & 3 & 1 & Potamogeton lucens & 4 & 3 \\
\hline Fontinalis antipyretica & 6 & 2 & Ranunculus sceleratus & 2 & 1 & Potamogeton natans & 4 & 1 \\
\hline Hygrohypnum sp. & 9 & 2 & Ranunculus trichophyllus & 6 & 2 & Potamoget. obtusifolius & 5 & 2 \\
\hline Leptodictyum riparium & 1 & 1 & Rorippa amphibia & 3 & 1 & Potamogeton pectinatus & 1 & 1 \\
\hline Palustriella commutata & 8 & 2 & Stachys palustris & 2 & 1 & Potamoget. perfoliatus & 4 & 2 \\
\hline Philonotis sp. & 9 & 2 & Utricularia vulgaris & 5 & 1 & Potamoget. praelongus & 6 & 3 \\
\hline Platyhypnidium riparioides & 5 & 1 & \multicolumn{3}{|l|}{ MONOCOTS } & Potamogeton pusillus & 4 & 2 \\
\hline Schistidium $s p$ & 8 & 2 & Acorus calamus & 2 & 3 & Sagittaria sagittifolia & 4 & 2 \\
\hline Sciuro-hypnum plumosum & 9 & 3 & Alisma lanceolatum & 4 & 2 & Scirpus sylvaticus & 3 & 1 \\
\hline Sphagnum sp. & 10 & 2 & Alisma plantago-aquatica & 4 & 2 & Sparganium emersum & 4 & 2 \\
\hline \multicolumn{3}{|c|}{ PTERIDOPHYTES } & Butomus umbellatus & 5 & 2 & Sparganium erectum & 3 & 1 \\
\hline Equisetum fluviatile & 6 & 2 & Calla palustris & 6 & 1 & Sparganium minimum & 7 & 1 \\
\hline Equisetum palustre & 5 & 2 & Carex acuta & 5 & 1 & Stratiotes aloides & 6 & 2 \\
\hline Thelypteris palustris & 6 & 1 & Carex acutiformis & 4 & 1 & Typha angustifolia & 3 & 2 \\
\hline \multicolumn{3}{|c|}{ DICOTYLEDONOUS } & Carex riparia & 4 & 2 & Typha latifolia & 2 & 2 \\
\hline Berula erecta & 4 & 2 & Carex vesicaria & 6 & 2 & Zannichellia palustris & 2 & 1 \\
\hline
\end{tabular}


Table 2. MIR indicator taxa in Kazakhstan

\begin{tabular}{|l|c|c|c|}
\hline \multirow{2}{*}{ Group of macrophytes } & \multirow{2}{*}{ MIR taxa in Poland } & \multicolumn{2}{|c|}{ MIR taxa in Kazakhstan } \\
\cline { 3 - 4 } & & Taxa & \% of Polish pool \\
\hline Vascular plants & 105 & 70 & 74 \\
\hline Bryophytes & 31 & 17 & 18 \\
\hline Algae & 15 & 7 & 7 \\
\hline Total - all aquatic macrophytes & 151 & 94 & 62 \\
\hline
\end{tabular}

atophyllum submersum, Potamogeton lucens and Potamogeton praelongus), floating free (Lemna gibba) and emergent (Menyanthes trifoliata and Acorus calamus). On the other hand, a strong representation of species with the $\mathrm{W}=2$ was found (50 species). These groups of macrophytes are still sensitive indicators.

Analysis of Kazakhstan flora revealed several aquatic plants that do not occur in Europe. Among them, five species were selected, to supplement the original list of MIR bioindicators for utilizing this method in Kazakhstan rivers. These are: Ranunculus altaicus, Ranunculus natans, Althenia filiformis, Nelumbo nucifera, Trapa incise. These species indicate different habitat preferences. Ranunculus altaicus, Ranunculus natans and Trapa incise are associated with low trophic waters. Nelumbo nucifera can indicate moderate trophy whereas Althenia filiformis is related with the highly eutrophic habitat.

Moreover, some species that occur in Poland, but have not been included in the MIR system in Poland, can be applied in the biological monitoring of rivers in Kazakhstan. This concerns some species which are relatively common in Kazakhstan which have not been used in the monitoring in Poland due to their scarce distribution. Among these species we have selected: Nuphar pumila, Nymphoides peltata, Ranunculus rionii, Rorippa palustris, Trapa natans, Utricularia intermedia, Utricularia minor, Eleocharis acicularis and Vallisneria spiralis. Among these species noteworthy is Utricularia intermedia and Utricularia minor, which are indicators of oligotrophic waters. The implementation of all new taxa requires research to

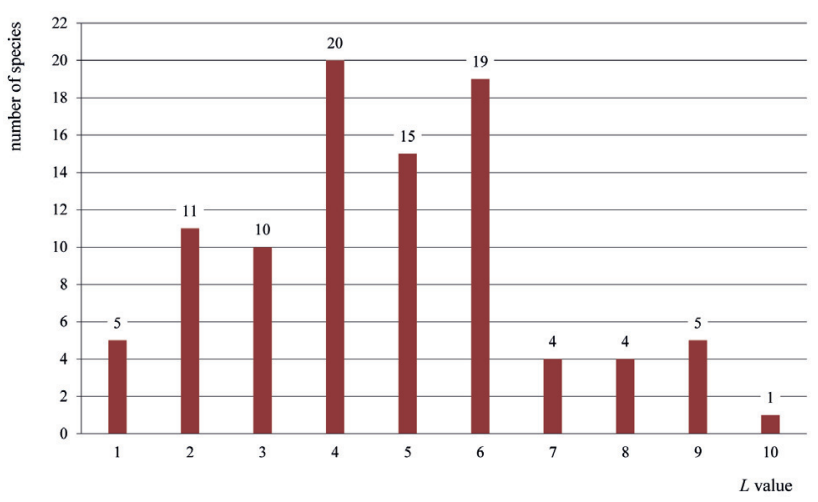

Fig. 1. Distribution of the MIR indicative species present in Kazakhstan according to the river quality value $(\mathrm{L})$ verify their ecological properties and to estimate for them the appropriate.

\section{Disscusion}

Analysis of the state of flora in Kazakhstan showed a relatively large number of macrophyte species (240 taxa) and it should be expected that the aquatic vegetation is even richer, since the state of aquatic flora identification is limited. The state of knowledge of the aquatic flora in Kazakhstan is weak and the number of publications on this topic is small. Publications which represent the diversity of aquatic plants are only Baitenov (1999), Sviridenko (2000) and Shadrina (2007). A particularly low level of identification concerns bryophytes and algae (except Charophytes). In recent years, information on the status of the flora in Kazakhstan has been complemented by a modern web portal, but this source is to be considered as required verification on academic level. It is expected that as a result of future botanical research more taxa will be confirmed among the Kazakhstan flora and the number of aquatic species will be increased. Thus, macrophyte diversity seems to be comparable to European conditions and a monitoring system based on aquatic plants can be organized in Kazakhstan on a comparable scale to Europe.

Preliminary comparative evaluation of indicator species of aquatic vegetation in Kazakhstan shows the possibility of the environmental assessment of rivers based on aquatic plants. Our analysis revealed that a large number of aquatic plants recorded in Kazakhstan are utilized as bioindicators

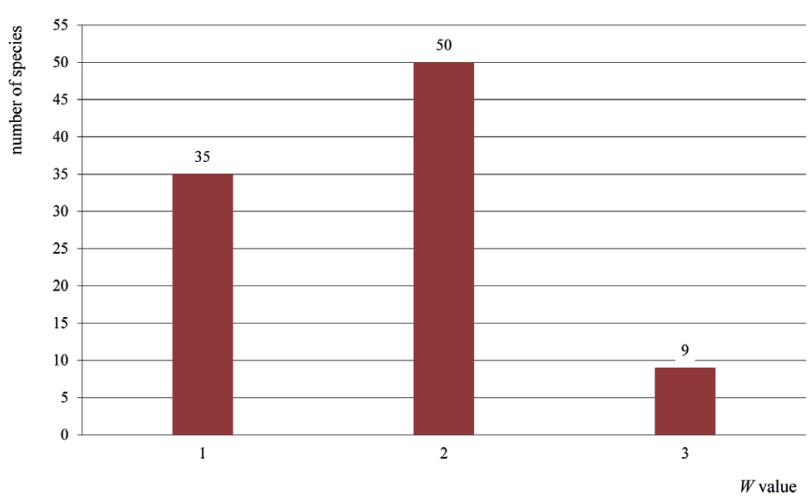

Fig. 2. Distribution of the MIR indicative taxa present in Kazakhstan according to the species weighting factor (W) 
in biological monitoring for ecological status assessment in rivers in Europe. We have confirmed that the majority of species utilised in the MIR system (62\%) are present in Kazakhstan. It can be expected that better recognition of aquatic flora in Kazakhstan will significantly increase this number, particularly in relation to the bryophytes.

The list of MIR species growing in Kazakhstan showed limited representation with respect to their species indicator value (L). We have found a very small number of species indicating oligotrophic water. To some extent, a similar situation concerns representation with respect to the species weighting factor (W) since the number of most sensitive indicators was nine. It seems to us that the introduction of new species from Kazakhstan to the system will complement the representation of the indicators of clean water.

The large number of indicative species used in the Polish system MIR proves that several European methods have the potential to be utilized in Kazakhstan. This is because the MIR system is very similar to the French system IBMR (Haury et al. 2006) and the British method MTR (Holmes et al. 1999). Moreover, other approaches can also be tested, such as methods from Denmark (Svendsen, Rebsdorf 1994) or Germany (Schaumburg et al. 2004). Probably, other biological elements utilized in EU monitoring can be introduced, such as macroinvertebrates, fish or diatoms. Our study proved that the introduction of the European approach for water assessment based on biological assessment has prospects for implementation in Kazakhstan and other countries in Central Asia.

\section{Conclusions}

- Aquatic flora in Kazakhstan is rich in species and, to a large extent, is similar to the flora in Poland.

- Among macrophytes present in Kazakhstan there are many plants used for biomonitoring under the MIR system. Moreover, there are many local species in Kazakhstan which can be introduced into macrophyte monitoring in this country.

- Basing on the taxonomic studies we found that the MIR index can be tested in Kazakhstan due to large representation of MIR indicative species. The system has a chance to be more effective if we enrich the list of indicative species with the local macrophytes.

Bibliography

Baitenov M.S, 1999, Flora of Kazakhstan, Volume 1. Illustrated families and genera, Gylym, Almaty, 400 pp.
Directive, 2000/60/EC, Water Framework Directive of the European Parliament and of the Council of 23 October 2000

Federenko W., 2011, innature.kz, Almaty, available at http://innature.kz (data access 1.10.2015)

Haury J., Peltre M.C., Tremolieres M., Barbe J., Thiebaut G., Bernez I., Daniel H., Chatenet P., Haan-Archipof G., Muller S., Dutartre A., Laplace-Treyture C., Cazaubon A., LambertServien E., 2006, A new method to assess water trophy and organic pollution - the Macrophyte Biological Index for Rivers (IBMR), its application to different types of river and pollution, [in:] Macrophytes in aquatic ecosystems: from biology to management, J.M. Caffrey, A. Dutartre, J. Haury, K.J. Murphy, P.M. Wade (eds.), Hydrobiologia, 570 (1), 153158, DOI: 10.1007/s10750-006-0175-3

Holmes N.T.H., Newman J.R., Chadd S., Rouen K.J., Saint L., Dawson F.H., 1999, Mean Trophic Rank, A user's manual. R\&D Technical Report E38, Environment Agency, Bristol, available at 1.10.2015 at https://www.gov.uk/government/uploads/system/uploads/attachment_data/file/290226/ stre38-e-e.pdf (data access 1.10.2015)

Krainyuk V., Abisheva K., Valikhanova A., Belyi A., Mirhashimov I., No V., Kuatbaeva G., 2005, Biological Diversity, Issue Brief, Astana, 72 pp. (in Russian), available at http://www. caresd.net/capacity/img/docs/70.pdf (data access 1.10.2015)

Ministry of Energy of the Republic of Kazakhstan, 2014, Water resources of Kazakhstan, Number ref: 17-01-352 on: 31.12.2014, Astana, 142 pp.

Nesterova S.G., Karipbaeva N.S., Polevik V.V., Pankiv I.G., 2013, Moss flora around the lake Dubygalinskoe East Kazakhstan region, The study of botanical diversity of Kazakhstan at the present stage, International Scientific Conference Dedicated to the Anniversaries of Prominent Botanists Kazakhstan, Almaty, 165-167

Ospanova M.O., Stamkulova K.Zh., 2012, The biodiversity of wetlands of avandelta of the Syrdarya river, Almaty, $65 \mathrm{p}$.

Pavlov N.V. (ed.), 1956-1966, Flora of Kazakhstan, AN Kazakhstan SSR, Alma-Ata, in 9 voliums (vol. 1, 1956; vol. 2, 1958; vol. 3, 1960; vol. 4, 5, 1961; vol. 6, 7, 1963; vol. 8, 1965; vol. 9, 1966 - all in Russian)

Protected natural territories of of Central Asia and Kazakhstan, 2007, available at http://www.iucnca.net/inforeserve1030 (data access 1.10.2015)

Republican State Enterprise, 2013, Kazakh Research Institute of Ecology and Climate, Report on the research work: "Scientific substantiation of ecological flow rivers of Kazakhstan for the balance of aquatic ecosystems" (Final Report for 2011-2012), The program No 003 "Scientific research in the field of environmental protection" (agreement with MEP RK 05-03-214 from 13.09.2011)

Schaumburg J., Schranz C., Foerster J., Gutowski A., Hofmann G., Meilinger P., Schneider S., Schmedtje U., 2004, Eco- 
logical classification of macrophytes and phytobenthos for rivers in Germany according to the water framework directive, Limnologica, 34 (4), 283-301, DOI: 10.1016/S00759511(04)80002-1

Schneider S., Krumpholz Th., Melzer A., 2000, Trophieindikation in Fließgewässern mit Hilfe des TIM (trophie-index makrophyten) - Erprobung eines neu entwickelten Index im Inninger Bach, Acta hydrochimica et hydrobiologica, 28 (5), 241-249

Semin V.A., Freyndling A.V., 1988, Macrophytes and their place in the system of ecological monitoring, Scientific basis for biomonitoring of freshwater ecosystems, [in:] Proceedings of the Soviet-French Symposium, L, 94-103

Shadrina N.V., 2007, Flora in the West Kazakhstan steppe province reservoirs, Abstract of dissertation for the degree of Candidate of Biological Sciences, Almaty, 26 pp.

Svendsen L., Rebsdorf A., 1994, Kvalitetssikring af Overvagningsdata, Retningslinier for Kvalitetssikring af Ferskvandskemiske Data i Vandmiljøplanenes Overvagningsprogram (Quality Assurance of Monitoring Data), Teknisk Anvisning fra DMU, 7, 1-87 (in Danish)
Sviridenko B.F., 2000, Flora and vegetation of reservoirs of North Kazakhstan, Omsk Pedagogical University, Omsk, Russia, 196 pp.

Szoszkiewicz K., Zbierska J., Jusik S., Zgoła T., 2010, Macrophyte Method of River Assessment - Methodological manual for the evaluation and classification of ecological status of rivers (in Polish), Bogucki Wydawnictwo Naukowe, Poznań, $81 \mathrm{pp}$.

The Global Biodiversity Information Facility, 2013, GBIF Backbone Taxonomy, available at http://www.gbif.org/species/2673526 on 2015-01-26 (data acces 1.10.2015)

Tremp H., Kohler A., 1995, The usefulness of macrophyte monitoring-systems, exemplified on eutrophication and acidification of running waters, Acta Botanica Gallica 142 (6), 541550, DOI: $10.1080 / 12538078.1995 .10515277$

Vilesov E.N., Naumenko A.A., Veselova L.K., Aubekerov B.Z., 2009, Physical Geography of Kazakhstan, Kazakh University, Almaty, $362 \mathrm{pp}$. 